\title{
Characterization of two types of azedinha in the region of Sete Lagoas, Brazil
}

\author{
Ernani C da Silva ${ }^{1}$; Lanamar de A Carlos ${ }^{1}$; Ana Paula Araújo ${ }^{1}$; Leila de CL Ferraz ${ }^{1}$; Marinalva W \\ Pedrosa $^{2}$; Luana Sabrine Silva ${ }^{1}$ \\ ${ }^{1}$ UFSJ, Campus Sete Lagoas, C. Postal 56, 35701-970 Sete Lagoas-MG; clarete@ufsj.edu.br; lanamar@ufsj.edu.br; anapaula_ufsj@ \\ hotmail.com; louback@ufsj.edu.br; luanasje07@yahoo.com.br; ${ }^{2}$ Unidade Regional EPAMIG Centro Oeste, Rod. MG 424, km 64, \\ 35701-970 Prudente de Morais-MG; marinalva@epamig.br
}

\begin{abstract}
Azedinha (Rumex acetosa) is a vegetable crop species consumed in natura in salads and pertains to the group of non-conventional vegetables. These rustic plants are often considered weeds plants. There exist two types of native azedinha in the Sete Lagoas region, Minas Gerais state, Brazil, that are usually grown in family gardens and here denominated Type I and Type II. In this study we characterized the morphologic, physic-chemical and chromatic characteristic of these two types of azedinha. The study was carried out in randomized complete blocks with four replications in dependences of the EPAMIG (Non-Conventional Vegetable Bank) in Prudente de Morais, Brazil. Plants were trained to the point of harvest, 90 days after the planting of seedlings, when they were harvested for analysis. We evaluated the characteristics on the leaves: weight, length, width, number of veins, width/length ratio, transverse and longitudinal diameter of the base of the petiole and longitudinal and transverse diameter ratio of the base of the petiole. We also evaluated the contents of macro and micronutrients and chemical characteristics of the plant. There are significant differences between the assessed characteristics between azedinha types I and II. We concluded that the plants probably belong to two different varieties.
\end{abstract}

Keywords: Rumex acetosa, physico-chemical characteristics, morphology.

\section{RESUMO}

Caracterização de dois tipos de azedinha nativas da região de Sete Lagoas-MG

A azedinha (Rumex acetosa) é uma espécie olerícola consumida in natura em saladas e integra o grupo de hortaliças não convencionais. As plantas são rústicas sendo muitas vezes consideradas "matos" e plantas daninhas. Existem dois tipos de azedinha nativas na região de Sete Lagoas, cultivadas normalmente em hortas familiares e aqui denominadas Tipo I e Tipo II. O objetivo deste trabalho foi caracterizar morfológica, físico-química e cromaticamente os dois tipos de azedinha nativos da região de Sete Lagoas. O trabalho foi conduzido em delineamento de blocos ao acaso com quatro repetições em área do Banco de Hortaliças Não Convencionais da EPAMIG, em Prudente de Morais-MG. As plantas foram conduzidas até ao ponto de colheita, 90 dias após o encanteiramento das mudas, quando foram colhidas e analisadas. Avaliou-se as características foliares: peso, largura, comprimento, número de nervuras, razão largura/comprimento, diâmetro transversal e longitudinal da base do pecíolo e razão diâmetro longitudinal e transversal da base do pecíolo. Foram avaliados os teores de macro e micronutrientes e as características bromatológicas e cromáticas da planta. Há diferenças significativas quanto às características avaliadas entre os tipos I e II de azedinha. Concluiu-se que as plantas analisadas, provavelmente, pertençam a duas cultivares distintas.

Palavras-chave: Rumex acetosa, características físico-quimicas, morfologia.

(Recebido para publicação em 5 de junho de 2012; aceito em 15 de abril de 2013) (Received on June 5, 2012; accepted on April 15, 2013)

$\mathrm{S}$ orrel (Rumex acetosa) is a vegetable crop species that belongs to the nonconventional vegetable group in Brazil (MAPA, 2010). It is cultivated in mild climate regions from Rio Grande do Sul to Minas Gerais. The leaves are eaten fresh in salads or cooked in soups (Leone, 2009). Its origin is not known for certain but it is found in the wild in mild climate regions of Europe and Asia and is spontaneous in Portugal (Lawrence, 1973).

Sorrel belongs to the Polygonaceae family. It is a perennial herbaceous plant with a fistulous, erect, striated stem that is frequently reddish in color, 20-60 cm tall and forms clumps with dozens of propagules (Lawrence, 1973; MAPA, 2010). It has a relatively high calcium oxalate content that limits consumption by people with kidney problems. In pharmacological terms, however, the plant has been indicated for treatment of jaundice, liver complaints, mouth sores and inflammation of the gallbladder (Balbach, 1992; Estrella, 1995).

There is variability but the plants are fairly similar and in practice local cultivars are selected and maintained. Two types of sorrel occur spontaneously in the region of Sete Lagoas, Minas Gerais, Brazil, that have contrasting phenotypic characteristics known locally as Type I and Type II. Type I plants are robust and larger than Type II plants (Figure 1). The leaves are larger and wider although the other characteristics are fairly similar.

Studies on seed morphology have attracted attention for some time, either as part of morphological and anatomical studies aiming to widen knowledge on a 
determined species or systematic plant grouping, or to recognize and identify the seedlings of a certain region within an ecological perspective (Oliveira, 1993).

Cultivar characterization is an essential step in certification, breeding and germplasm conservation programs, because it allows monitoring of the genetic quality (IPGRI, 2003). Genetic markers are any characteristics, biochemical processes or DNA fragments that distinguish genetically different individuals (Silva et al., 2010). Four types of markers have been used in plants: morphological, cytological, biochemical and molecular (Borém \& Miranda, 2005). Molecular markers are chromosome segments that can be used to detect differences between two or more individuals (Borém \& Miranda, 2005). Morphological characteristics are manifested by structural components of the plants and their value is enhanced by their constancy, and they can be used with confidence to identify species (Lawrence, 1973).

Although biochemical, morphological and molecular descriptors can be used, the morphological descriptors, because they are simple to apply, have been the most used to characterize germplasm and identify genotypes and cultivars (Melo et al., 2009).

Thus the objective of the present research was to study the morphology, physic-chemical and chromatic characteristics of two types of sorrel native to the region of Sete Lagoas in the state of Minas Gerais, Brazil.

\section{MATERIAL AND METHODS}

The study was carried out in areas of the EPAMIG Unconventional Vegetable Bank in the municipality of Prudente de Morais-MG (19028'33"'S, 4411'53"W, $769 \mathrm{~m}$ altitude); it has the AW type climate (tropical wet and dry or savanna) with a dry winter, $22.1^{\circ} \mathrm{C}$ mean annual temperature and $1340 \mathrm{~mm}$ mean annual rainfall.

Two types (I and II) of sorrel plants native to the Sete Lagoas region were studied and kept in the EPAMIG Unconventional Vegetable Bank. Both present phenotype differences in terms of stand, coloring and leaf shape suggesting that they are different types of sorrel. The seedlings were produced from tillers removed from healthy plants, planted in a nursery and when rooted were transplanted to the experimental area. The study was carried out in a randomized block design with four replications and the treatments were characterized by two types of sorrel. The plots consisted of 16 plants conducted in $13 \times 30 \mathrm{~cm}$ spacing in $1.2 \mathrm{~m}$ wide nursery beds containing four rows. The four central plants were considered the useful plot. Crop and plant health treatments were carried out according to the recommendations for the species (MAPA, 2010).

Ninety days after nursery planting the four central plants from each useful plot were harvested and one plant was taken randomly from each replication to assess the morphological characteristics (weight, width, length, number of veins on the left and right side of the leaf blade, leaf blade width and length ratio, petiole base transversal diameter and longitude and petiole base transversal diameter and longitude ratio. The assessments were made on five leaves removed randomly from each plant.

The bromatological characteristics total lipids (ether extract), crude fiber, fixed mineral residue (ASH) and moisture content were determined according to techniques described by the AOAC (1992). Total nitrogen was determined according to the method by Kjeldahl (AOAC 1992).

The plant coloring was measured on leaves of each type of sorrel using the $L^{*}$. $a^{*}, b^{*}$ system supplied by a model CR 410 Konica Minolta colorimeter, read on three different points on the surface of each leaf. In this color system, $\mathrm{L}^{*}$ represents luminosity $\left(\mathrm{L}^{*}=0\right.$ - black and $\mathrm{L}^{*}=100$-white) and $\mathrm{a}^{*}$ and $\mathrm{b}^{*}$ are coordinates of colors responsible for chrome: $\left(+a^{*}\right.$ is red and $-\mathrm{a}$ is green, $+\mathrm{b}^{*}$ is yellow and $-b^{*}$ is blue (Hunterlab, 1996). For the mineral composition analysis (macro and micro nutrients) ten leaves were collected randomly from the four central plants of each plot, placed in Kraft paper bags and dried in a forced air circulation chamber at $45^{\circ} \mathrm{C}$ for 72 hours. The material was ground in a Wiley-type grinder with a 30 mesh sieve and stored in hermetically closed flasks. The macro- and micronutrients analyzed were nitrogen $(\mathrm{N})$, phosphorus $(\mathrm{P})$, potassium $(\mathrm{K})$ calcium $(\mathrm{Ca})$ magnesium $(\mathrm{Mg})$, sulfur $(\mathrm{S})$ iron $(\mathrm{Fe})$ zinc $(\mathrm{Zn})$ manganese $(\mathrm{Mn})$ copper $(\mathrm{Cu})$ and boron (B). $\mathrm{N}$ was determined by the Nessler method (Jackson, 1965); P by colorimetry, $\mathrm{K}$ by flame photometry, $\mathrm{Ca}, \mathrm{Mg}, \mathrm{Fe}, \mathrm{Zn}, \mathrm{Cu}$ and $\mathrm{Mn}$ by atomic absorption spectrophotometry and $\mathrm{S}$ by turbidimetry with barium chloride (Jones Junior et al., 1991; Malavolta et al., 1997).

The data were submitted to analysis of variance and the means compared by the Tukey test with $5 \%$ probability.

\section{RESULTS AND DISCUSSION}

The characteristics leaf blade weight, length and width and the petiole base transversal diameter and longitude of Type I sorrel plants were significantly greater than those of the leaves of Type II sorrel plants (Table 1). These values showed the greater stand in Type I plants that was clearly seen in the field (Figure 1) and were in agreement with Silva Junior (2012) who reported sorrel leaves ranging from 20 to $25 \mathrm{~cm}$ long by 5 to $8 \mathrm{~cm}$ wide. Although the plant stand was different, there were no significant differences for the number of veins and the leaf blade width-length ratio. The leaf blade width and length in the Type I plants were significantly greater than the leaf blade in the Type II plants, the width length ratio indicated leaves with narrow blade and the same shape for both types. The petiole base transversal diameter and longitude ratio of the leaves of the Type I plants was significantly greater than that of the leaves of the Type II plants, but there were no significant differences in relation to the petiole base longitudinal diameter. However, significant differences were observed for the ratio between the diameters showing a larger and flattened petiole shape for the Type I plants and a smaller and rounded petiole base for the Type II plants. 
Table 1. Morphological characteristics for types I and II of Rumex acetosa (características morfológicas relativas aos tipos I e II de Rumex acetosa). Sete Lagoas, UFSJ, 2012.

\begin{tabular}{lccccccccc}
\hline Types & $\begin{array}{c}\text { PF } \\
(\mathbf{g})\end{array}$ & $\begin{array}{c}\text { LF } \\
(\mathbf{c m})\end{array}$ & $\begin{array}{c}\text { CF } \\
(\mathbf{c m})\end{array}$ & RLCF & NNLE & NNLD & $\begin{array}{c}\text { DTBP } \\
(\mathbf{m m})\end{array}$ & $\begin{array}{c}\text { DLBP } \\
(\mathbf{m m})\end{array}$ & RDLDT \\
\hline I & $4.09 \mathrm{a}$ & $8.94 \mathrm{a}$ & $18.63 \mathrm{a}$ & $0.47 \mathrm{a}$ & $6.09 \mathrm{a}$ & $7.20 \mathrm{a}$ & $5.06 \mathrm{a}$ & $3.18 \mathrm{a}$ & $0.66 \mathrm{~b}$ \\
$\mathrm{II}$ & $2.04 \mathrm{~b}$ & $6.43 \mathrm{~b}$ & $12.47 \mathrm{~b}$ & $0.51 \mathrm{a}$ & $7.05 \mathrm{a}$ & $6.90 \mathrm{a}$ & $3.11 \mathrm{~b}$ & $3.14 \mathrm{a}$ & $1.11 \mathrm{a}$ \\
\hline CV $(\%)$ & 16.05 & 5.24 & 6.57 & 5.08 & 11.21 & 12.42 & 17.87 & 19.68 & 20.08 \\
\hline
\end{tabular}

* Means followed by the same letter in the columns did not differ from each other by the Tukey test, (p<0.05) [médias seguidas por letras distintas nas colunas diferem entre si ao nivel de significância de $5 \%$ pelo teste de Tukey $(\mathrm{p}<0.05)] ; \mathrm{PF}=$ leaf weight $(\mathrm{PF}=\mathrm{peso}$ da folha); $\mathrm{LF}=$ width of leaf blade ( $\mathrm{LF}=$ largura do limbo foliar); $\mathrm{CF}=$ length of leaf blade $(\mathrm{CF}=$ comprimento do limbo foliar); $\mathrm{RLCF}=$ ratio width:length of the leaf blade $(\mathrm{RLCF}=$ relação largura:comprimento do limbo foliar); NNLE and NNLD respectively= number of ribs on the left and right side of the leaf blade, respectively (NNLE e NNLD= número de nervuras do lado esquerdo e direito do limbo foliar, respectivamente); DTBP and DLBP, respectively= transverse and longitudinal diameter of the base of the petiole (DTBP e DLBP= diâmetro transversal e longitudinal da base do pecíolo, respectivamente); RDLDT= ratio of longitudinal and transverse diameter of the base of the petiole (RDLDT= relação diâmetro longitudinal e diâmetro transversal da base do pecíolo).

Table 2. Contents of macro and micronutrients for types I and II of Rumex acetosa (teores de macro e micronutrientes relativas aos tipos I e II de Rumex acetosa). Sete Lagoas, UFSJ, 2012.

\begin{tabular}{|c|c|c|c|c|c|c|c|c|c|c|c|}
\hline \multirow{2}{*}{ Types } & \multicolumn{6}{|c|}{ Macronutrients (mg/g) } & \multicolumn{5}{|c|}{ Micronutrients (mg/kg)* } \\
\hline & $\mathbf{N}$ & $\mathbf{P}$ & $\mathbf{K}$ & $\mathbf{C a}$ & Mg & $\mathbf{S}$ & $\mathbf{F e}$ & Mn & $\mathbf{C u}$ & $\mathbf{Z n}$ & B \\
\hline $\bar{I}$ & $26.2 \mathrm{a}$ & $5.1 \mathrm{a}$ & $40.2 \mathrm{a}$ & $5.9 \mathrm{a}$ & $5.5 \mathrm{a}$ & $2.0 \mathrm{a}$ & $205 b$ & $44.5 \mathrm{a}$ & $4.3 \mathrm{a}$ & $13.6 \mathrm{~b}$ & $37.0 \mathrm{ab}$ \\
\hline II & $17.3 \mathrm{~b}$ & $3.4 \mathrm{~b}$ & $33.4 \mathrm{~b}$ & $6.1 \mathrm{a}$ & $5.1 \mathrm{a}$ & $1.2 \mathrm{~b}$ & $258 \mathrm{a}$ & $20.1 \mathrm{~b}$ & $1.4 \mathrm{~b}$ & $29.9 \mathrm{a}$ & $38.5 \mathrm{a}$ \\
\hline $\mathrm{CV}(\%)$ & 9.6 & 6.4 & 10.1 & 11.5 & 12.3 & 13.1 & 15.6 & 18.3 & 18.8 & 18.5 & 19.4 \\
\hline
\end{tabular}

* Means followed by the same letter in the columns did not differ from each other by the Tukey test, $\mathrm{p}<0.05$ (médias seguidas por letras distintas nas colunas diferem entre si ao nivel de significância de $5 \%$ pelo teste de Tukey $(\mathrm{p}<0.05))$.

Table 3. Bromatological and chromatic content in leaves of two types of Rumex acetosa (conteúdo bromatológico e cromático em folhas de dois tipos de Rumex acetosa). Sete Lagoas, UFSJ, 2012.

\begin{tabular}{lrrr}
\hline \multirow{2}{*}{ Characteristics } & \multicolumn{2}{c}{ Types* } & \multirow{2}{*}{ CV (\%) } \\
\cline { 2 - 3 } & \multicolumn{1}{c}{ I } & \multicolumn{1}{c}{ II } & \\
\hline Crude protein (\%) & $15.82 \mathrm{a}$ & $15.88 \mathrm{a}$ & 1.81 \\
Fiber, neutral detergent (\%) & $36.95 \mathrm{a}$ & $36.79 \mathrm{a}$ & 4.54 \\
Ashes (\%) & $12.40 \mathrm{a}$ & $12.35 \mathrm{a}$ & 1.04 \\
Lipid fraction (\%) & $2.28 \mathrm{a}$ & $2.27 \mathrm{a}$ & 2.21 \\
Dry mass (\%) & $80.86 \mathrm{a}$ & $79.38 \mathrm{a}$ & 0.99 \\
pH & $3.22 \mathrm{a}$ & $2.05 \mathrm{~b}$ & 0.70 \\
Total soluble solids ( ${ }^{\circ} \mathrm{BRIX)}$ & $4.37 \mathrm{~b}$ & $6.20 \mathrm{a}$ & 2.99 \\
Titratable acidity (citric acid, g/100 g of & $0.11 \mathrm{~b}$ & $0.20 \mathrm{a}$ & 12.59 \\
fresh matter) & & & \\
L $^{*}$ & $47.12 \mathrm{a}$ & $41.04 \mathrm{~b}$ & 0.86 \\
$\mathrm{a}^{*}$ & $-17.67 \mathrm{a}$ & $-15.57 \mathrm{~b}$ & 2.11 \\
$\mathrm{~B}^{*}$ & $30.95 \mathrm{a}$ & $25.34 \mathrm{~b}$ & 1.31 \\
\hline
\end{tabular}

*Means followed by the same letter in the lines did not differ from each other by the Tukey test, $\mathrm{p}<0.05$ (médias seguidas por letras distintas nas linhas diferem entre si ao nível de significância de $5 \%$ pelo teste de Tukey $(\mathrm{p}<0.05))$.

In terms of macronutrients, except for calcium $(\mathrm{Ca})$ the Type I plants presented significantly greater content in the leaves (Table 2). This indicated a different dynamic for macro nutrient absorption and better nutrition in the plants.

The data showed different absorption and nutrition for the micronutrients (Table 2). The manganese (Mn) and copper $(\mathrm{Cu})$ contents were significantly greater for the Type I plants while the iron $(\mathrm{Fe})$ and zinc $(\mathrm{Zn})$ contents were significantly greater in the Type II plants and the sulfur (S) content did not differ significantly. These data can serve as reference for sorrel nutrition.

In terms of bromatological content, the two types of sorrel presented significant differences only for the characteristics titratable acidity and total soluble solids (Table 3 ) where the Type II presented the highest contents.

There were significant differences in the instrumental color results in the three chromatic parameters studied indicating differences in the coloring of the two types of sorrel (Table 3).

In instrumental color determination, it is known that the $\mathrm{L}^{*}$ value expresses the luminosity or clarity of the sample, and ranges from 0 to 100 ; thus when the sample is closer to 100 it is lighter but darker when it is more distant. Although the two types had medium clarity, Type 

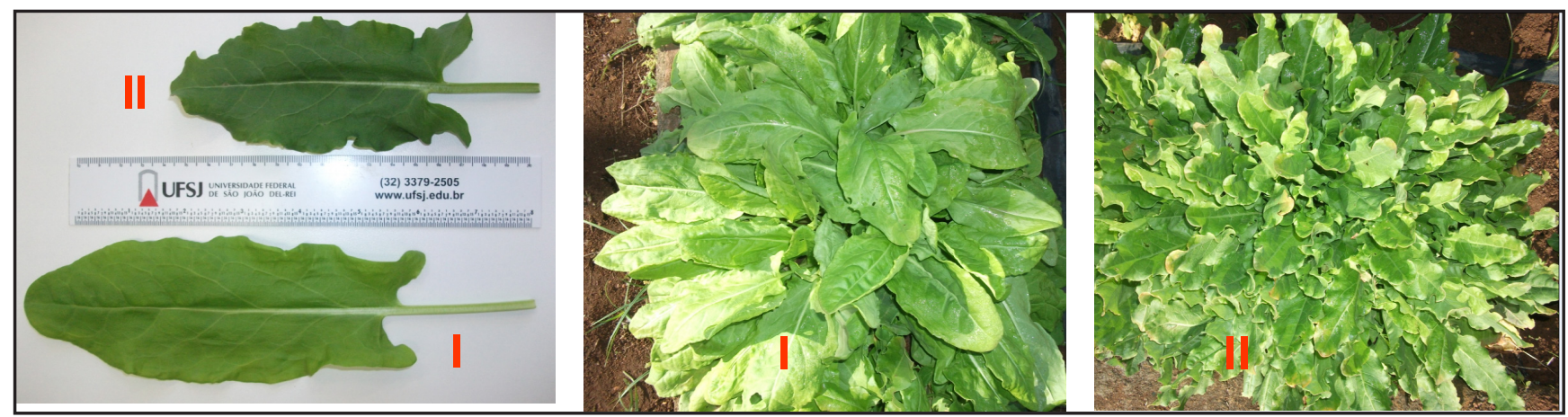

Figure 1. Images of Rumex acetosa (azedinha) types I and II [imagens de Rumex acetosa (azedinha) tipos I e II]. Sete Lagoas, UFSJ, 2012.

I was significantly lighter than the Type II plants. The most positive $a^{*}$ values indicate a tendency to red coloring, and more negative to green coloring. It was observed in both types that the $\mathrm{a}^{*}$ values were negative indicating green color of the leaves. However, the value -17.67 (Type I) indicated a significantly greener tonality in its leaves compared to the value of -15.57 found for the Type II leaves. More positive $b^{*}$ values express greater yellow intensity and more negative a greater blue intensity. The $b^{*}$ values were positive for the two types of sorrel indicating greater yellow intensity for the Type I leaves.

The data showed that sorrel Types I and II are morphologically different in terms of leaf characteristics, differ for mineral nutrition (macro and micronutrient contents) and differ for leaf coloring. Thus it was concluded that the plants analyzed probably belong to two different cultivars.

\section{REFERENCES}

AOAC - ASSOCIATION OF OFFICIAL ANALYTICAL CHEMISTS. 1992. Official Methods of Analysis of the Association of Official Analytical Chemistry. 11. ed. Washington: DC: AOAC. 1115p.

BALBACH A. 1992. As plantas curam. Itaquaquecetuba: Missionária. 296p.

BORÉM A; MIRANDA GV. 2005. Melhoramento de plantas. 4.ed. Viçosa: UFV.525p.

ESTRELLA E. 1995. Plantas medicinales amazônicas: realidad y perspectivas. Lima: Tratado de Cooperacion Amazonica. 302p.

HUNTERLAB. 1996. Applications Note. 8:7, Disponível em http://www.hunterlab.com, acessado em 11 de abril de 2012.

IPGRI-International Plant Genetic Resources Institute. 2003. Descriptors for Rambutan (Nephelium lappaceum). Rome. 54p.

JACKSON ML.1965. Soil chemical analysis. New Jersey: Prentice Hall, 498p.

JONES JUNIOR JB; WOLF BMHA.1991. Plant Analysis Handbook: a practical sampling, preparation, analysis, and interpretation guide. Athens (USA): Micro-Macro Publishing, 213p.

LAWRENCE GHM. 1973. Taxonomia das Plantas Vasculares. Lisboa: Fundação Calouste
Gulbenkian, 296 p.

LEONE RS. 2009. Desenvolvimento de suco misto de frutas e hortaliça para a melhoria da qualidade nutricional e funcional. Viçosa: UFV. 105p (Dissertação mestrado).

MALAVOLTA E; VITTI GC; OLIVEIRA SA.1997. Avaliação do estado nutricional das plantas: princípios e aplicações. Piracicaba: POTAFOS, 319p.

MAPA. 2010. Manual de hortaliças nãoconvencionais. Brasília: Mapa/ACS, $92 \mathrm{p}$.

MELO RA; MENEZES D; RESENDE LV; WANDERLEY JÚNIOR LJG; MELO PCT; SANTOS VF. 2009. Caracterização morfológica de genótipos de coentro. Horticultura Brasileira 27: 371-376.

OLIVEIRA EC. 1993. Morfologia de plântulas. In: AGUIAR IB; PIÑA RODRIGUES FCM; FIGLIOLIA MB (eds). Sementes florestais tropicais. Brasília: ABRATES, p.175-214.

SILVA JUNIOR AA 2012.. Plantas medicinais e aromáticas, PROMED - Projeto Plantas Medicinais,153p. Disponível em: http://www. scribd.com/doc/66524200/21/AZEDINHADA-HORTA. Acessado em 10 de abril de 2012.

SILVA SA; SILVA-MANN R; CARVALHO SVA. 2010. Diversidade genética e seleção assistida por marcadores moleculares RAPD em populações de alface. Scientia Plena 6: 1-9. 